\title{
STRUCTURAL EQUQTION MODELING PADA MODEL KESELAMATAN DAN KESEHATAN KERJA DENGAN IKLIM KERJA SEBAGAI VARIABEL MODERASI
}

\author{
JAMIATUR RAHMAN \\ Fakultas Ekonomi Universitas Mercu Buana Yogyakarta \\ Email: rahman jamiatur@yahoo.com \\ AUDITA NUVRIASARI \\ Prodi Manajemen Universitas Mercu Buana Yogyakarta \\ Email: audita@mercubuana-yogya.ac.id
}

\begin{abstract}
Abstrak
Pentingnya Keselamatan dan kesehatan kerja (K3) adalah untuk mengatur dinamika proses dalam perusahaan agar tidak terjadi malproduksi serta menjamin keamanan dan kenyamanan karyawan dalam bekerja, sehingga keselamatan dan kesehatan kerja yang baik didukung oleh iklim/lingkungan kerja yang baik pula, dengan demikian akan memberikan dampak yang positif terhadap efektifitas dan produktivitas kinerja perusahaan.

Tujuan penelitian ialah untuk mengetahui bagaimana keselamatan dan kesehatan kerja berpengaruh terhadap kinerja perusahaan, bagaimana iklim kerja berpengaruh terhadap kinerja perusahaan, bagaimana keselamatan dan kesehatan kerja berpengaruh terhadap iklim kerja dan bagaimana keselamatan dan kesehatan kerja berpengaruh terhadap kinerja perusahaan dengan iklim kerja sebagai variabel moderasi di D.I.Yogyakarta yang berasal dari tujuh sektor: sektor jasa, sektor koperasi, sektor bank, sektor ukm, sektor manufaktur, sektor perdagangan, sektor tehnologi dengan jumlah 105 karyawan. Penelitian ini menggunakan metode pengumpulan data kuisoner dan data yang diperoleh kemudian dianalisa menggunakan analisis data SEM(Structural Equation Model).

Hasil penelitian membuktikan bahwa ada pengaruh signifikan keselamatan dan kesehatan kerja terhadap kinerja perusahaan dan tidak ada pengaruh signifikan iklim kerja terhadap kinerja perusahaan dan adanya pengaruh yang signifikan keselamatan dan kesehatan kerja terhadap iklim kerja perusahaan dan adanya pengaruh yang signifikan iklim kerja yang memperkuat keselamatan dan kesehatan kerja terhadap kinerja perusahaan.
\end{abstract}

Kata kunci: Keselamatan dan kesehatan kerja, Iklim/lingkungan kerja, Kinerja perusahaan dan SEM (Structural Equation Model).

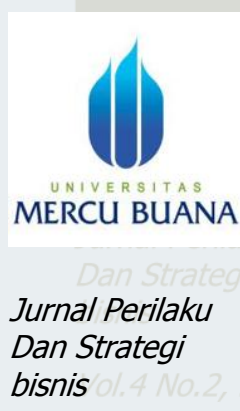

Vol. 4 No.2, 2016

Hal. $85-107$

\section{PENDAHULUAN}

Dalam aspek ekonomi, manusia berperan sebagai subjek yaitu orang yang memerankan pelaku ekonomi, dalam dunia bisnis kegiatan ekonomi sangat dipengaruhi oleh manusia yang terlibat di dalamnya. Sehingga segala aktifitas manusia yang berhubungan dengan kegiatan bisnis merupakan hal yang menarik untuk diamati, untuk mengetahui sejauh mana peran dan eksistensi manusia yang terlibat dalam kegiatan ekonomi. Dalam sebuah perusahaan atau organisasi karyawan merupakan sumber daya 
manusia yang sangat berharga bagi suatu perusahaan dan menjadi kunci sukses keberhasilan suatu perusahaan. Oleh karena itu sumber daya manusia dalam perusahaan harus dikelola dengan baik sehingga perusahaan dapat berjalan dengan baik.

Menurut Patrick L. Romano (1989), "Pengukuran kinerja (performansi) merupakan salah satu proses dalam sistem pengendali manajemen dengan membandingkan dan mengevaluasi antara rencana yang dibuat dan hasil yang dicapai, menganalisa penyimpangan yang terjadi dan melakukan perbaikan". Sehingga dapat disimpulkan bahwa pengukuran kinerja merupakan salah satu proses dalam sistem

pengendalian manajemen dengan membandingkan antara kinerja orang-orang dari organisasi lain dengan pekerjaan yang sama. Menurut Swanson (2004), "Kinerja organisasi adalah kinerja organisasi mempertanyakan apakah tujuan dan misi suatu organisasi telah sesuai dengan kenyataan kondisi atau faktor ekonomi, politik, dan budaya yang ada, apakah struktur dan kebijakannya mendukung kinerja yang diinginkan, apakah memiliki kepemimpinan, modal dan infrastruktur dalam mencapai misinya, apakah kebijakan budaya dan sistem insentifnya mendukung pencapaian kinerja yang diinginkan, dan apakah organisasi tersebut menciptakan dan memelihara kebijakan-kebijakan seleksi dan pelatihan sumber daya nya".

Kinerja organisasi merupakan gambaran hasil kerja organisasi dalam mencapai tujuannya yang tentunya di pengaruhi oleh sumber daya yang dmiliki oleh organisasi tersebut. Sumber daya yang di maksud dapat berupa fisik seperti sumber daya manusia maupun nonfisik seperti peraturan, informasi, dan kebijakan, maka pengukuran kinerja juga bisa dengan menggunakan indikator-indikator kinerja yang ada untuk melihat

dan mengetahui apakah organisasi tersebut sudah melaksanakan tugas dengan baik dan untuk mengetahui tujuannya sudah tercapai atau belum. Seperti yang kita ketahui tenaga kerja merupakan aset negara maupun perusahaan yang harus diberi perlindungan terhadap aspek keselamatan dan kesehatan kerja (K3), mengingat ancaman bahaya yang berhubungan dengan kerja. Dan bersumber dari hukum dasar Indonesia yang tertinggi yaitu Undang-undang Dasar (UUD) 1945 sebagai sumber

hukum dari segala hukum. Sumber hukum peraturan perundangan keselamatan dan kesehatan kerja (K3) berlandaskan pada pasal 27 ayat 2 UUD Tahun 1945 yang menyatakan bahwa "Tiap-tiap warga negara berhak atas pekerjaan dan penghidupan yang layak bagi kemanusiaan".

Pemerintah Indonesia sampai-sampai mengatur keselamatan kerja dengan undangundang ketenagakerjaan No.13 / tahun 2003, pasal 86 dan 87 pada bab perlindungan, pengupahan dan kesejahteraan. Pasal 87 ayat (1) berbunyi "Setiap perusahaan wajib menerapkan sistem manajemen keselamatan dan kesehatan kerja yang terintegrasi dengan sistem manajemen perusahaan". Dan undang-undang No.18 tahun 1999 yang mengatur tentang kewajiban penyelenggara konstruksi untuk memenuhi

ketentuan tentang keteknikan, keamanan, keselamatan dan kesehatan kerja serta perlndungan tenaga kerja, dan tata lingkungan setempat.

Sebuah contoh dari Kementerian tenaga kerja dan transmigrasi senantiasa melakukan pembenahan sistem penempatan dan perlindungan tenaga kerja Indonesia (TKI) sejak pra penempatan, selama penempatan maupun setelah penempatan. Selain itu, Kemnakertrans 
pun telah melakukan memberlakukan pengetatan dalam penempatan TKI, terutama untuk pekerja sektor domestik. Sehingga saat ini tidak semua calon TKI

yang ingin bekerja di luar negeri bisa berangkat. Untuk mendukung hal tersebut, Menteri Tenaga Kerja dan Transmigrasi kembali mengadakan sosialisasi slogan TKI " Jangan Berangkat Sebelum Sehat" atau disingkat JBSS ke berbagai daerah yang menjadi basis atau kantong TKI di seluruh Indonesia (www.depnakertrans.go.id/news), diakses pada tanggal 13 Oktober, 2014 ).

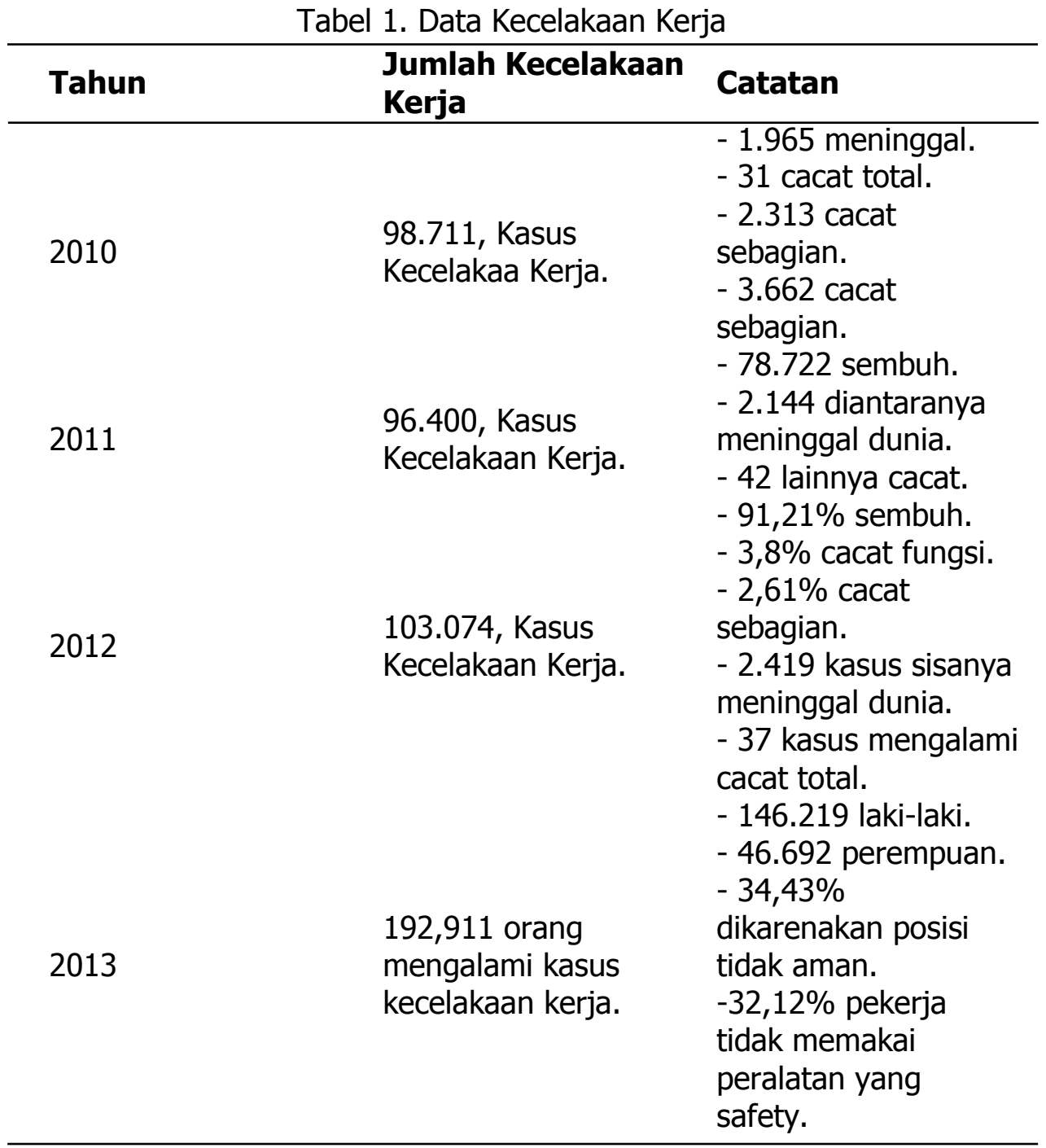

Sumber: Badan Penyelenggara Jaminan Sosial, 2014

Berdasar tabel diatas maka, makin penting keselamatan kerja bagi karyawan. Seperti yang sudah dijelaskan kesehatan dan keselamatan kerja merupakan hal yang harus diperhatikan oleh perusahaan maupun tenaga kerja itu sendiri. Selain itu, kesehatan dan keselamatan kerja merupakan suatu upaya untuk meningkatkan suasana kerja yang aman, nyaman, efektif dan bertujuan untuk meningkatkan efektifitas kinerja sumber daya manusia dan kinerja organisasi dalam suatu perusahaan dalam Tahun Jumlah Kecelakaan Kerja

Catatan 2010 terjadi 98.711, Kasus Kecelakaa Kerja, dimana 1.965 meninggal, 31 cacat total, 2.313 cacat sebagian, 3.662 cacat sebagian, 78.722 sembuh. Tahun 201196.400 , 
Kasus Kecelakaan Kerja, dimana 2.144 diantaranya meninggal dunia, 42 lainnya cacat. Tahun 2012 terdapat 103.074 Kasus Kecelakaan Kerja, dimana 91,21\% sembuh, 3,8\% cacat fungsi, 2,61\% cacat sebagian, 2.419 kasus sisanya meninggal dunia, 37 kasus mengalami cacat total, Tahun 2013 terdapat 192,911 orang mengalami kasus kecelakaan kerja, dimana 146.219 laki-laki, 46.692 perempuan, 34,43\% dikarenakan posisi tidak aman, 32,12\% pekerja tidak memakai peralatan yang safety.

Berdasar ulasan diatas, dapat disimpulkan bahwa menjadi penting untuk mengetahui seberapa efektif peran kinerja sumber daya nusia ini pada perusahaan dan organisasi, dari sudut pandang Keselamatan dan Kesehatan Kerja (K3). Menurut kajian ilmiah "High performance human resource practices and organizational performance: (HPHRP) The mediating role of occupational safety and health" (Simon C.H. Chan, Wai-ming Mak, 2012). Temuan Hasil penelitiannya mendukung validitas pembangunan dari pengukuran awal dari HPHRP dengan penyertaan dari sebuah pengukuran pada OSH. Peran mediasi dari Iklim kenyamanan yang dirasakan dalam hubungan dari HPHRP dan Kinerja Organisasi juga yang telah dikonfirmasikan. Diadopsi pada kondisi di Indonesia saat ini dengan keselamatan dan kesehatan kerja (K3).

\section{Rumusan Masalah}

Adapun yang menjadi pokok permasalahan sebagai berikut :

1. Bagaimana keselamatan dan kesehatan kerja (K3) mempengaruhi kinerja perusahaan?

2. Bagaimana iklim kerja mempengaruhi kinerja perusahaan?

3. Bagaimana keselamatan dan kesehatan kerja mempengaruhi iklim kerja?

4. Bagaimana keselamatan dan kesehatan kerja (K3) mempengaruhi kinerja perusahaan dengan iklim kerja sebagai variabel moderasi?

\section{Tujuan Penelitian}

Adapun yang menjadi tujuan penelitian adalah :

1. Untuk mengetahui Bagaimana keselamatan dan kesehatan kerja (K3) mempengaruhi kinerja perusahaan?

2. Untuk mengetahui Bagaimana Iklim kerja mempengaruhi kinerja perusahaan?

3. Untuk mengetahui Bagaimana Keselamatan dan Kesehatan Kerja mempengaruhi Iklim Kerja?

4. Untuk mengetahui Bagaimana Keselamatan dan kesehatan kerja (K3) mempengaruhi kinerja perusahaan dengan iklim kerja sebagai variabel moderasi?

\section{LANDASAN TEORI}

\section{Keselamatan dan kesehatan kerja (K3)}

Menurut P2K3 Depnaker RI (2000) secara filosofi kesehatan dan keselamatan merupakan suatu pemikiran dan upaya umtk menjamin keutuhaan dan kesempurnaan baik jasmaniah maupun rohaniah tenaga kerja khususnya dan manusia pada umumnya, hasil karya dan budayanya menuju masyarakat adil dan makmur. Keselamatan kerja merupakan keselamatan yang bertalian dengan mesin, pesawat, alat kerja, bahan dan pengolahannya, landasan tempat kerja dan lingkungannya serta cara-cara melakukan pekerjaan (Suma'mur, 1989). Suma'mur, (1996), keselamatan kerja merupakan spesialisasi ilmu kesehatan beserta prakteknya yang bertujuan agar para pekerja atau masyarakat pekerja memperoleh derajat kesehatan setinggi-tingginya baik fisik, mental maupun sosial dengan usaha preventif dan 
kuratif terhadap penyakit/gangguan kesehatan yang diakibatkan oleh faktor pekerjaan dan lingkungan serta terhadap penyakit umum.

Menurut Felton (1990) dalam (Budiono dkk, 2003) mengemukakan pengertian tentang kesehatan kerja adalah "Occupational Health is the extension of the principles and practice of occupational medicine, to include the conjoint preventive or constructive activities of all members of the occupational health team", Pengembangan prinsip-prinsip dan praktik dari kedokteran kerja, untuk memadukan kegiatan-kegiatan yang bersifat mencegah atau membangun dari seluruh anggota tim kesehatan kerja.

Menurut Ridley, John (1983), mengartikan kesehatan dan keselamatan kerja adalah suatu kondisi dalam pekerjaan yang sehat dan aman baik itu bagi pekerjaannya, perusahaan maupun bagi masyarakat dan lingkungan sekitar pabrik atau tempat kerja tersebut. Jackson (1999), menjelaskan bahwa kesehatan dan keselamatan kerja menunjukkan kepada kondisikondisi fisiologis-fisikal dan psikologis tenaga kerja yang diakibatkan oleh lingkungan kerja yang disediakan oleh perusahaan.

Di tinjau dari sudut pandang keilmuan, kesehatan dan keselamatan kerja adalah ilmu pengetahuan dan penerapannya dalam usaha mencegah kemungkinan terjadinya kecelakaan dan penyakit akibat kerja di tempat kerja. (Lalu Husni, 2003), Sedangkan pengertian secara keilmuan, menurut Armanda (2006) adalah suatu ilmu pengetahuan dan penerapannya dalam usaha mencegah kemungkinan terjadinya kecelakaan dan penyakit akibat kerja. Menurut Mangkunegara (2002), Suatu pemikiran dan upaya untuk menjamin keutuhan dan kesempurnaan jasmani maupun rohani tenaga kerja pada khususnya dan manusia pada umumnya, serta hasil karya dan budaya untuk menuju masyarakat adil dan makmur.

Di dalam UU.K-3 No. 1 tahun 1970 ditegaskan:

a. Setiap tenaga kerja mendapatkan perlindungan atas keselamatannya, dalam melakukan pekerjaan untuk kesejahteraan hidup dan meningkatkan produksi serta produktivitas nasional.

b. Bahwa setiap orang lain yang berada di tempat kerja perlu terjamin pula keselamatannya. c. Setiap sumber produksi perlu dipelihara, sehingga dapat dipakai secara aman dan efisien. Menurut Budiono dkk (2003), faktor-faktor yang mempengaruhi Keselamatan dan Kesehatan Kerja (K3) antara lain:

a. Beban kerja.

Beban kerja berupa beban fisik, mental dan sosial, sehingga upaya penempatan pekerja yang sesuai dengan kemampuannya perlu diperhatikan.

b. Kapasitas kerja.

Kapasitas kerja yang banyak tergantung pada pendidikan, keterampilan, kesegaran jasmani, ukuran tubuh, keadaan gizi dan sebagainya.

c. Lingkungan kerja.

Lingkungan kerja yang berupa faktor fisik, kimia, biologik, ergonomik, maupun psikososial.

Studi telah menyatakan bahwa praktek-praktek keselamatan dan kesehatan kerja karyawan isu harus diprioritaskan karena meningkatnya kesadaran karyawan kesejahteraan di tempat kerja (Clarke, 1999). Karyawan mengalami potensi ancaman di OSH mungkin menghadapi serangkaian masalah fisiologis, psikologis dan emosional, yang akhirnya mempengaruhi 
kinerja organisasi (Zacharatos et al., 2005). Hal ini penting untuk mengintegrasikan aspek yang berbeda dari praktek sumber daya manusia dan mengembangkan pemahaman tentang bagaimana iklim keamanan yang dirasakan secara sinergis mempengaruhi kinerja organisasi (Delery dan Doty, 1996). Sebagai persepsi individu dari berbagai berbagai aspek keselamatan di lingkungan kerja, seperti prosedur keselamatan dan keamanan kinerja (Clarke, 1999). Griffin dan Neal (2000) telah menemukan iklim keselamatan diprediksi kepatuhan keselamatan dan partisipasi. Iklim keamanan yang dirasakan telah ditemukan memiliki dampak yang signifikan terhadap kecelakaan kerja di industri makanan dan minuman.

Berdasarkan beberapa uraian di atas mengenai pengertian keselamatan dan pengertian kesehatan kerja, bahwa dapat disimpulkan mengenai pengertian keselamatan dan kesehatan kerja (K3) adalah suatu bentuk usaha atau upaya bagi para pekerja untuk memperoleh jaminan atas keselamatan dan kesehatan kerja (K3) dalam melakukan pekerjaan yang mana pekerjaan tersebut dapat mengancam dirinya yang berasal dari individu sendiri dan lingkungan kerjanya.

\section{Keselamatan Kerja}

Menurut Mangkunegara (2002), bahwa indikator penyebab keselamatan kerja yang meliputi:

a. Keadaan tempat lingkungan kerja, yang meliputi:

1. Penyusunan dan penyimpangan barang-barang yang berbahaya yang kurang diperhitungkan keamanannya.

2. Ruang kerja yang terlalu padat dan sesak.

3. Pembuangan kotoran dan limbah yang tidak pada tempatnya.

b. Pemakaian peralatan kerja yang meliputi:

1. Pengamanan peralatan kerja yang sudah usang dan rusak.

2. Penggunaan mesin, alat elektronik tanpa pengaman yang baik pengaturan penerangan.

Iklim keselamatan kerja Pengertian Iklim keselamatan Kerja Hofmann dan Stetzer (1996) bahwa konstruk iklim adalah "individu melampirkan makna dan menafsirkan lingkungan diman amereka bekerja. Makna ini untuk dan persepsi kemudian mempengaruhi cara di mana individu berperilaku dalam organisasi melalui sikap, norma, dan persepsi perilaku".

\section{Faktor-faktor Iklim keselamatan kerja Kerja}

Menurut Griffin and Neal mengukur keselamatan yang terdiri dari lima sistem meliputi:

1. Management Value (Nilai Manajemen)

Nilai manajemen menunjukkan seberapa besar manajer dipersepsikan menghargai keselamatan di tempat kerja, bagaimana sikap manajemen terhadap keselamatan, dan persepsi bahwa keselamatan penting.

2. Safety Communucation (Komunikasi Keselamatan)

Komunikasi keselamatan diukur dengan menanyakan dimana

isu-isu keselamatan dikomunikasikan.

3. Safety Practices (Praktek Keselamatan)

Yaitu sejauh mana pihak manajemen menyediakan peralatan keselamatan dan merespon dengan cepat terhadap bahaya-bahaya yang timbul.

4. Safety Training (Pelatihan Keselamatan) 
Pelatihan adalah aspek yang sangat krusial dalam sistem personalia dan mungkin metode yang sering digunakan untuk menjamin level keselamatan yang memadai di organisasi karena pelatihan sangat penting bagi pekerja produksi.

5. Safety Equipment (Peralatan Keselamatan)

Peralatan keselamatan mengukur tentang kecukupan peralatan keselamatan, seperti alatalat perlengkapan yang tepat disediakan dengan mudah.

\section{Kesehatan Kerja}

Status kesehatan seseorang, menurut Blum (1981) ditentukan oleh empat faktor yakni:

1. Lingkungan, berupa lingkungan fisik (alami, buatan) kimia (organik/anorganik, logam berat, debu), biologik (virus, bakteri, mikroorganisme) dan ssosial budaya (ekonomi, pendidikan, pekerjaan).

2. Perilaku yang meliputi sikap, kebiasaan dan tingkah laku.

3. Pelayanan kesehatan: promotif, preventif, perawatan, pengobatan,pencegahan kecacatan, rehabilitasi, dan Genetik, yang merupakan faktor bawaan setiap manusia.

Interaksi dari berbagai faktor tersebut sangat mempengaruhi tingkat kesehatan seseorang baik dalam kehidupan sehari-hari maupun di tempat kerja. Dengan demikian, dalam pengelolaan kesehatan keempat faktor tersebut perlu diperhatikan, khususnya dalam aspek lingkungaan dan pelayanan kesehatan, hubungan antara pekerjaan dan kesehatan seseorang mulai dikenal sejak beberapa abad yang lalu, antara lain dengan didapatkannya penyakit akibat cacing atau gejala sesak napas akibat timbunan debu dalam paru pada pekerja pertambangan.

Kaitan timbal balik pekerjaan yang dilakukan dan kesehatan pekerja semakin banyak dipelajari dan terus berkembang sejak terjadinya revolusi industri. Pekerjaan mungkin berdampak negatif bagi kesehatan akan tetapi sebaliknya pekerjaan dapat pula memperbaiki tingkat kesehatan dan kesejahteraan pekerja bila dikelola dengan baik, demikian pula status kesehatan pekerja sangat mempengaruhi peningkatan kinerja perusahaan menjadi lebih baik, karena Pekerjaan yang sehat memungkinkan tercapainya hasil kerja yang lebih baik bila dibandingkan dengan tenaga kerja yang terganggu kesehatannya.

\section{Kecelakaan Kerja}

Menurut PERMENAKER No. 03/MEN/1998 kecelakaan adalah suatu kejadian yang tidak dikehendaki dan tidak diduga semula yang dapat menimbulkan korban manusia dan atau harta benda. Kecelakan kerja dapat dibagi menjadi dua kategori yaitu:

1. Kecelakaan industri (industrial accident); kecelakaan yang terjadi di tempat kerja karena adanya sumber bahaya atau bahaya kerja.

2. Kecelakaan dalam perjalanan (commuty accident); kecelakaan yang terjadi di luar lingkungan kerja dalam kaitannya dengan adanya hubungan kerja (P2K3 Depnaker RI, 200).

Menurut Simajuntak (1994), Kecelakaan kerja adalah kecelakaan atau penyakit yang diderita oleh seseorang akibat melakukan suatu pekerjaan atau ditimbulkan oleh lingkungan kerja. Terdapat banyak faktor yang menimbulkan kecelakaan dan penyakit kerja. Kecelakaan dan penyakit kerja dapat terjadi pada saat seseorang mengoperasikan alat kerja atau produksi, antara lain karena: 
1. Pekerja yang bersangkutan tidak terampil atau tidak mengetahui cara mengoperasikan alat-alat tersebut.

2. Pekerja tidak hati-hati, lalai, terlalu lelah atau dalam keadaan sakit.

3. Tidak tersedia alat-alat pengaman.

4. Alat kerja atau produksi yang digunakan dalam kesedaan tidak baik atau tidak layak pakai lagi.

Kecelakaan dan penyakit akibat kerja dapat pula terjadi karena kondisi dan lingkungan kerja yang tidak aman, misalnya dalam bentuk ledakan, kebakaran, dan kebocoran atau perembesan unsur-unsur kimia berbahaya. Bencana kecelakaan kerja tersebut dapat menimbulkan korban dan kerugian dalam bentuk:

1. Pekerja dan atau orang lain meninggal atau luka.

2. Alat-alat produksi rusak.

3. Bahan baku dan bahan produksi lainnya rusak.

4. Bangunan terbakar atau roboh.

5. Proses produksi terhenti atau terganggu.

Menurut Simajuntak (1994), kecelakaan kerja dapat dikategorikan dalam beberapa akibat yang ditimbulkannya seperti :

a. Meninggal dunia, termasuk kecelakaan yang paling fatal yang menyebabkan penderita meninggal dunia walaupun telah mendapatkan pertolongan dan perawatan sebelumnya.

b. Cacat permanen total adalah cacat yang mengakibatkan penderita secara permanen tidak mampu lagi melakukan pekerjaan produktif karena kehilangan atau tidak berfungsinya lagi bagian-bagian tubuh, seperti: kedua mata, satu mata dan satu tangan atau satu lengan atau satu kaki. Dua bagian tubuh yang tidak terletak pada satu ruas tubuh.

c. Cacat permanen sebagian adalah cacat yang mengakibatkan satu bagian tubuh hilang atau terpaksa dipotong atau sama sekali tidak berfungsi.

d. Tidak mampu bekerja sementara, dimaksudkan baik ketika dalam masa pengobatan maupun karena harus beristirahat menunggu kesembuhan, sehingga ada hari-hari kerja hilang dalam arti yang bersangkutan tidak melakukan kerja produktif.

\section{Iklim/ Lingkungan kerja}

Lingkungan merupakan salah satu faktor penting yang harus diperhatikan, berdasarkan pandangan sistem terbuka, organisasi merupakan bagian dari lingkungan, kecocokan organisasi dengan lingkungannya mengacu pada kemampuan dan kesesuaian organisasi dengan kebutuhan dan keinginan pelanggan, ekonomi, serikat pekerja dan lainnya. Menurut George R, Terry (2006), lingkungan kerja dapat diartikan sebagai kekuatan-kekuatan yang mempengaruhi, baik secara langsung maupun tidak langsung terhadap kinerja organisasi ataupun perusahaan.

Pengertian lain tentang lingkungan kerja menurut Amirullah Haris Budiyono (2004), bahwa lingkungan kerja merujuk pada lembaga- lembaga atau kekuatan-kekuatan yang berada di dalam maupun di luar organisasi tersebut dan secara potensial mempengaruhi kinerja organisasi itu. Menurut Fautisno Cardoso Gomes (2003), lingkungan kerja adalah proses kerja dimana lingkungan saling berinteraksi menurut pola tertentu, dan masing-masing memiliki karakteristik dan/atau nilai-nilai tertentu mengenai organisasi yang tidak akan lepas dari pada lingkungan dimana organisasi itu berada, dan manusianya yang merupakan sentrum segalanya. 
Menurut Alex S Nitisemito (2003), mendefinisikan lingkungan kerja sebagai berikut : "Lingkungan kerja adalah segala sesuatu yang ada disekitar para pekerja yang dapat mempengaruhi dirinya dalam menjalankan tugas-tugas yang diembankan". Menurut Sedarmanyati (2001), mendefinisakan lingkungan kerja sebagai berikut : "Lingkungan kerja adalah keseluruhan alat perkakas dan bahan yang dihadapi, lingkungan sekitarnya di mana seseorang bekerja, metode kerjanya, serta pengaturan kerjanya baik sebagai perseorangan maupun sebagai kelompok".

Menurut uraian diatas dapat disimpulkan bahwa lingkungan kerja merupakan komponenkomponen yang merujuk pada lembaga atau kekuatan yang berinteraksi langsung maupun tidak langsung menurut pola tertentu mengenai organisasi atau perusahaan yang tidak akan lepas dari pada lingkungan dimana organisasi atau perusahaan itu berada dan lingkungan kerja juga sebagai segala sesuatu yang ada di sekitar karyawan pada saat bekerja baik yang berbentuk fisik maupun non fisik, langsung ataupun tidak langsung yang mempengaruhi dirinya bekerja dan tenaga kerja saat bekerja.

Menurut Wibowo (2007), lingkungan kerja yang bisa memotivasi karyawan untuk meningkatkan kinerjanya dapat dibedakan menjadi 2 (dua) yaitu :

a. Lingkungan Internal

Ada banyak faktor yang mempengaruhi kinerja atau prestasi kerja karyawan, karyawan akan bekerja dengan produktif atau tidak tergantung pada kondisi pekerjaan yang secara langsung ataupun tidak langsung akan berdampak pada kelangsungan perusahaan, Menurut Wibowo (2007), lingkungan internal adalah komponen-komponen yang ada dalam lingkup organisasi atau perusahaan. Adapun faktor-faktor yang mempengaruhi lingkungan internal, yaitu :

a. Kompetensi

Kompetensi adalalah suatu kemampuan untuk melaksanakan suatu pekerjaan atau tugas yang dilandasi atas keterampilan dan pengetahuan serat didukung oleh sikap pekerja yang dituntut oleh pekerjaan tersebut.

b. Kepuasan Kerja

Keadaan emosional yang menyenangkan atau tidak menyenangkan dimana para karyawan memandang pekerjaan mereka. Kepuasan kerja mencerminkan perasaan seseorang terhadap pekerjaannya. Ini nampak dalam sikap positif ataupun negatif karyawan terhadap pekerjaan dan segala sesuatu yang dihadapi dilingkungan kerja. Kepuasan kerja mempengaruhi tingkat absensi, perputaran tenaga kerja, semangat kerja, keluhan-keluhan, dan masalah-masalah lainnya. Dengan demikian hubungan kepuasan kerja akan mengarahkan kepelaksanaan kerja lebih baik atau sebaliknya, prestasi kerja menimbulkan kepuasan.

c. Strees karyawan

Berbagai bentuk kekuatiran dan masalah selalu dihadapi para karyawan, stress adalah suatu kondisi ketegangan yang mempengaruhi emosi, proses berfikir dan kondisi seseorang. Stress yang terlalu besar dapat mengancam kemampuan seseorang untuk menghadapi lingkungan, hampir setiap kondisi pekerjaan bisa menyebabkan stress tergantung pada reaksi karyawan. Diantara kondisi kerja yang tersebut, yaitu : beban kerja berlebihan, tekanan atau desakan waktu, wewenang yang tidak mencukupi untuk melaksanakan tanggung jawab. 


\section{b. Lingkungan Eksternal}

Organisasi atau perusahaan seharusnya tidak hanya memusatkan perhatian pada lingkungan internal organisasi, tetapi perlu juga menyadari penting pengaruh lingkungan eksternal terhadap kinerja karyawan yang akan berdampak pada organisasi yang dikelola. Menurut Wibowo (2007), lingkungan eksternal adalah komponen-komponen yang ada diluar organisasi atau perusahaan, bagaimana juga lingkungan eksternal saat ini sangat bergejolak, perubahan-perubahan yang terjadi didalamnya sangat dinamis dan kadangkadang pengaruhnya tidak dapat diperkirakan terlebih dahulu,karena manajemen dituntut untuk selalu bersikap tanggap, selalu mengikuti dan menyesuaikan diri dengan lingkungan yang selalu berubah, adapun faktor-faktor yang mempengaruhi kinerja karyawan dari lingkungan eksternal yaitu :

\section{a. Sektor Sosial Ekonomi}

Setiap segi sosial ekonomi dapat membantu atau mengahmbat upaya mencapai tujuan perusahaan dan menyebabkan keberhasilan ataupun kegagalan strategi, nilai-nilai terwujud ke dalam perubahan gaya hidup yang mempengaruhi permintaan terhadap produk dan jasa ataupun perusahaan berhubungan dengan karyawan serta interaksi karyawan terhadap pekerjaan, meliputi : masalah kesehatan, perubahan-perubahan di sekitar tempat tinggal atau tekanan sosial.

b. Sektor Teknologi

Disamping sektor sosial ekonomi, perubahan teknologi dapat memberi peluang besar untuk meningkatkan hasil, tujuan, atau mengancam kedudukan perusahaan karena akan berinteraksi secara langsung maupun tidak langsung terhadap karyawan.

c. Sektor Pemerintah

Falsafah pemerintah dalam hubungan dengan perusahaan dapat berubah-ubah sewaktu-waktu, ini merupakan aspek penting yang harus diperhatikan oleh perusahaan, tindakan pemerintah dapat memperbesar peluang atau hambatan usaha atau adakala keduanya bersamaan, disamping mendorong dan membantu, pemerintah juga menciptakan ancaman, berarti mempengaruhi kelangsungan hidup dan keuntungan perusahaan, dengan ada peraturan pemerintah, maka akan berdampak pada perusahaan dan akan berimbas pada kinerja karyawan yang secara keseluruhan akan berinteraksi secara langsung maupun tidak langsung.

\section{Kinerja Perusahaan}

Pada suatu individu, keompok, maupun organisasi diperlukan suatu penilaian untuk mengetahui tujuan akhir yang ingin dicapai atau sering disebut dengan kinerja, penilaian kinerja ini sangat penting dilakukan karena hal ini dapat digunakan sebagai ukuran keberhasilan organisasi atau perusahaan dalam mencapai misinya, selain itu, kinerja dapat digunakan untuk mengukur tingkat prestasi atau kebijakan individu maupun kelompok individu. Kinerja adalah hasil pencapaian dari usaha yang telah dilakukan yang dapat diukur dengan indikator-indikator tertentu, indikator kinerja organisasi ialah: jumlah keuntungan yang diperoleh, jumlah produk yang dihasilkan atau layanan yang dihasilkan atau diberikan kepada pelanggan (Fuad Mas'ud :2004: 40).

Menurut Keban (2004), Kinerja merupakan terjemahan dari performance yang sering diartikan sebagai "penampilan", "unjuk rasa" atau "prestasi" hal ini juga sependapat dengan yang dikatakan Mangkunegara (2008), bahwa istilah kinerja berasal dari kata job 
performance atau actual performance yakni prestasi kerja atau prestasi yang ingin dicapai. Menurut uraian diatas maka kinerja merupakan terjemahan dari performance yang sering diartikan sebagai penampilan, unjuk rasa, atau prestasi. Kinerja adalah gambaran mengenai tingkat pencapaian pelaksanaan suatu kegiatan/program/kebijakan dalam mewujudkan sasaran, tujuan, misi dan visi organisasi (Mahsun, 2006).

Menurut keban (2004), pencapaian hasil (kinerja) dapat dinilai menurut pelaku yaitu :

1. Kinerja individu yang menggambarkan sampai seberapa jauh seseorang telah melaksanakan tugas pokok sehingga dapat memberikan hasil yang telah ditetapkan oleh kelompok atau instansi.

2. Kinerja kelompok, yaitu menggambarkan sampai seberapa jauh seseorang telah melaksanakan tugas pokoknya sehingga dapat memberikan hasil yang telah ditetapkan oleh kelompok atau instansi.

3. Kinerja organisasi yaitu menggambarkan sampai seberapa jauh satu kelompok telah melaksanakan semua kegiatan pokok sehingga mencapai visi dan misi institusi.

Organisasi yang sehat adalah organisasi yang struktur wewenang (kekuasaan), sistem nilai, norma, sistem imbalan dan sanksi (hukuman), beroprasi dengan baik sehingga dapat mendukung tujuan organisasi, serta kesejahteraan para anggotanya. Kesehatan organisasi mungkin merupakan istilah yang dapat dipahami dan didefinisakan secara berbeda-beda baik oleh pihak luar maupun dalam organisasi. Hal ini karena sehat merupakan istilah yang mengandung nilai. Nilai yang direfleksikan oleh bagaimana kita memandang dan menafsirkan perilaku. Oleh karena itu, istilah kesehatan organisasi bersifat persepsi. Namun demikian, penting untuk diingat bahwa orang berperilaku berdasarkan pada persepsinya. Kita dapat memahami dan mempelajari nilai dan keyakinan dalam sebuah organisasi dengan memperhatikan dan mengamati perilaku para anggota organisasi.

Beberapa standar yang paling sering digunakan untuk mengukur kesehatan organisasi antara lain : produktivitas, semangat kerja (morale), komitmen (loyalitas), dan tingkat kepercayaan atau iklim organisasional. Organisasi yang sehat memiliki visi dan misi yang jelas dan selalu konsisten dengan prinsip-prinsip dasar yang dianut bersama dalam organisasi. Organisasi yang para anggotanya merasa memiliki martabat, kebanggaan, mempunyai kesempatan untuk dapat mengembangkan kemampuan. Lingkungan organisasi yang saling menghormati, percaya, terbuka, keadilan dalam pemberian imbalan dan memungkinkan anggota untuk menyalurkan kemampuan yang dimiliki, serta tiadanya rasa ketakutan yang dimiliki orang anggota. Di samping itu, organisasi dapat beradaptasi dengan baik terhadap lingkungan eksternalnya.

\section{Penelitian Sebelumnya}

Beberapa penelitian yang telah dilakukan oleh para peneliti sebelumnya yang dianggap ada relevansinya dengan penelitian yang dilakukan oleh penulis antara lain adalah penetitian yang dilakukan Fahmawati dan Batu Bara. Fahmawati (2004), meneliti dengan judul "Pengaruh Kesehatan dan Keselamatan Kerja (K3) Serta Lingkungan Kerja Terhadap Kinerja Karyawan pada PT. Cahaya Surya Tunas Tapioka Wonogiri". Hasil uji F menunjukkan bahwa kesehatan dan keselamatan kerja serta lingkungan kerja mempunyai pengaruh yang signifikan terhadap kinerja karyawan sebesar, hasil uji t menunjukkan bahwa Kesehatan dan Keselamatan Kerja berpengaruh signifikan terhadap kinerja karyawan dan hasil uji $t$ menunjukkan bahwa lingkungan kerja berpengaruh signifikan terhadap kinerja karyawan 
dan koefisien determinan menunjukkan bahwa variabel bebas (kesehatan dan keselamatan kerja serta lingkungan kerja) dapat menjelaskan terhadap variabel terikat (kinerja karyawan). Khaerurahman (2007) meneliti dengan judul "Pengaruh Kesehatan dan Keselamatan Kerja (K3) Terhadap Kinerja Karyawan Pada PT. Sinar Sosro Cabang Gresik". Hasil uji $\mathrm{F}$ menunjukkan bahwa kesehatan dan keselamatan kerja mempunyai pengaruh yang signifikan terhadap kinerja karyawan hasil uji t menunjukkan bahwa keselamatan kerja berpengaruh signifikan terhadap kinerja karyawan dan kesehatan kerja mempunyai pengaruh signifikan terhadap kinerja, koefisien determinasi ( $R$ square) menunjukkan bahwa variabel bebas (Kesehatan dan Keselamatan Kerja) dapat menjelaskan terhadap variabel terikat (Kinerja Karyawan).

\section{Pengembangan Hipotesis}

Berdasarkan rumusan masalah yang telah dikemukakan sebelumnya, maka teori yang mengerucut pada hipotesis dalam penelitian ini adalah sebagai berikut:

Menurut Ridley, John (1983), mengartikan kesehatan dan keselamatan kerja adalah suatu kondisi dalam pekerjaan yang sehat dan aman baik itu bagi pekerjaannya, perusahaan maupun bagi masyarakat dan lingkungan sekitar pabrik atau tempat kerja tersebut.

H1 : Diduga Keselamatan dan Kesehatan Kerja (K3) berpengaruh positif terhadap kinerja Perusahaan.

Menurut George R, Terry (2006), lingkungan kerja dapat diartikan sebagai kekuatankekuatan yang mempengaruhi, baik secara langsung maupun tidak langsung terhadap kinerja organisasi ataupun perusahaan. Karyawan mengalami potensi ancaman di OSH mungkin menghadapi serangkaian masalah fisiologis, psikologis dan emosional, yang akhirnya mempengaruhi kinerja organisasi (Zacharatos et al., 2005).

H2 : Diduga Iklim kerja berpengaruh positif terhadap kinerja Perusahaan.

Menurut Amirullah Haris Budiyono (2004), bahwa lingkungan kerja merujuk pada lembagalembaga atau kekuatan-kekuatan yang berada di dalam maupun di luar organisasi tersebut dan secara potensial mempengaruhi kinerja organisasi itu.

H3 : Diduga Keselamatan dan Kesehatan Kerja akan mempengaruhi positif terhadap Iklim/Lingkungan Kerja.

Menurut Fautisno Cardoso Gomes (2003), lingkungan kerja adalah proses kerja dimana lingkungan saling berinteraksi menurut pola tertentu, dan masing-masing memiliki karakteristik dan/atau nilai-nilai tertentu mengenai organisasi yang tidak akan lepas dari pada lingkungan dimana organisasi itu berada, dan manusia yang merupakan sentrum segalanya.

H4 : Diduga Iklim Kerja akan memperkuat Keselamatan dan Kesehatan Kerja (K3) terhadap Kinerja Perusahaan.

\section{Kerangka pikir penelitian}

Keselamatan dan Kesehatan Kerja dan Iklim Kerja memiliki suatu tujuan yaitu menimbulkan dampak kinerja perusahaan menjadi baik dan

berkembang. Berikut adalah bagan kerangka pikir penelitian dengan judul: Dampak keselamatan dan kesehatan kerja (K3) terhadap kinerja perusahaan dengan iklim kerja sebagai variabel mediasi dan moderasi yaitu dengan menggunakan Model Penelitian dibawah :

Gambar 1. Model Moderasi Iklim/Lingkungan Kerja 
Keselamatan dan kesehatan Kerja (K3)

Kinerja perusahaan

Iklim Kerja

\section{METODOLOGI PENELITIAN}

\section{Lokasi Penelitian}

Pengamatan ini merupakan suatu studi yang dilaksanakan secara langsung pada objek amatan, lokasi objek amatan pada penelitian ini ialah di daerah Provinsi Daerah Istimewa Yogyakarta, subjek penelitian karyawan yang sedang atau telah bekerja pada lembaga/perusahaan yang memiliki program k3 alasan saya mengambil subjek amatan secara keseluruhan untuk mewakili setiap perusahaan yang ada di D.I. Yogyakarta.

\section{Populasi dan sampel}

Populasi adalah sekelompok orang, benda, atau hal yang menjadi sumber pengambilan sampel; suatu kumpulan yang memenuhi syarat tertentu yang berkaitan dengan masalah penelitian, sedangkan sampel merupakan bagian bagian dari populasi (sekaran et al, 2010). Teknik pengambilan sampel yang akan dilakukan oleh peneliti adalah dengan cara random sampling.

Populasi yang dipilih dalam peneliti ini adalah seluruh karyawan yang sedang bekerja atau telah bekerja di D.I.Yogyakarta yang berasal dari tujuh Sektor yaitu: Sektor jasa, Sektor koperasi, Sektor bank, Sektor ukm, Sektor manufaktur, Sektor perdagangan, Sektor tehnologi. Sedangkan total sampel yang digunakan dalam penelitian ini adalah 105 responden.

\section{Teknik Analisis Data}

Teknik analisis data yang digunakan untuk membahas permasalahan dalam penelitian ini adalah Structural Equation Model (SEM).

\section{HASIL PENELITIAN}

Tabel 2. Responden menurut jenis kelamin

\begin{tabular}{lll}
\hline Jenis kelamin & Jumlah responden & Presentase \\
\hline Perempuan & 48 & $40 \%$ \\
Laki-laki & 57 & $60 \%$ \\
\hline Total & 105 & $100 \%$ \\
\hline
\end{tabular}

Tabel diatas menunjukan bahwa responden dengan jenis kelamin laki-laki lebih banyak yaitu sebanyak $57(60 \%)$ di bandinkan responden dengan jenis kelamin perempuan yang jumlahnya 48 (40\%).

Tabel 3. Responden berdasarkan usia

\begin{tabular}{lll}
\hline Usia $\quad$ Jumlah responden & Presentase (\%) \\
\hline
\end{tabular}




\begin{tabular}{lll}
$<20$ & 3 & $1 \%$ \\
$21-30$ & 69 & $69 \%$ \\
$31>$ & 33 & $30 \%$ \\
\hline Total & 105 & $100 \%$ \\
\hline
\end{tabular}

Tabel diatas menunjukan bahwa responden dengan usia dibawah 20 tahun yaitu sebanyak 3 (1\%), dan responden dengan usia rata-rata sampai 30 tahun yaitu sebanyak 69 (69\%), dan responden dengan usia 31 keatas sebanyak 33(30\%), maka total keseluruhan responden berdasarkan usia yaitu 105 orang.

Tabel 4. Responden berdasarkan Tenaga Kerja

\begin{tabular}{lll}
\hline Tenaga Kerja & Jumlah Responden & Presentase (\%) \\
\hline Sektor Jasa & 24 & $22 \%$ \\
Sektor Koperasi & 3 & $1 \%$ \\
Sektor Bank & 5 & $5 \%$ \\
Sektor Ukm & 27 & $27 \%$ \\
Sektor Manufaktur & 35 & $35 \%$ \\
Sektor Perdagangan & 2 & $1 \%$ \\
Sektor Tehnologi & 9 & $9 \%$ \\
\hline Total & 105 & $100 \%$ \\
\hline
\end{tabular}

Setiap responden memiliki pengalaman dan masa kerja yang berbeda-beda dan itu akan mempengaruhi tingkat dalam pengembangan karier setiap karyawan. Berikut adalah data responden berdasarkan bidang kerja.

\section{Analisis Kuantitatif}

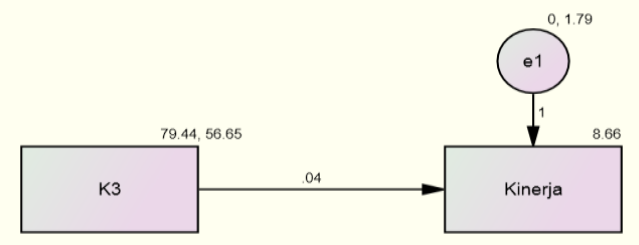

Tabel 5. Regression Weights:

\begin{tabular}{|c|c|c|c|c|c|}
\hline Estimate & & S.E. & C.R. & $\mathrm{P}$ & Label \\
\hline Kinerja & $<---$ & K3 & .042 & .017 & 2.405 \\
\hline
\end{tabular}

Tabel diatas menunjukan signifikan dengan probabilitas diatas $\%(P=0,016)$ dan dengan $\mathrm{T}$ hitung sebesar: 2,405

Tabel 6. Intercepts (Koefisien)

\begin{tabular}{lllll}
\hline Estimate & S.E. & C.R. & P & Label \\
Kinerja & 8.657 & 1.388 & 6.236 & $* * *$ \\
\hline
\end{tabular}

Sehingga tabel 5 dan 6 bisa membentuk metode persamaan regresinya sebagai berikut: 


$$
\begin{gathered}
Y^{\prime}=a+b X \\
Y^{\prime}=8,657+0,042
\end{gathered}
$$

Angka-angka ini dapat diartikan sebagai berikut:

Intercepts sebesar 8,657; artinya jika keselamatan dan kesehatan kerja (K3) (X), nilainya adalah 0, maka Kinerja perusahaan nilainya yaitu sebesar 8,657.

Koefisien regresi variabel K3 (X)sebesar 0,042; artinya jika keselamatan dan kesehatan kerja naik 1\%, maka kinerja perusahaan $(Y)$ akan mengalami peningkatan sebesar 0,042. Koefisien bernilai positif artinya terjadi hubungan positif antara keselamatan dan kesehatan kerja dengan kinerja perusahaan, semakin meningkat keselamatan dan kesehatan kerja maka semakin meningkatkan kinerja perusahaan tersebut dengan berkurang kecelakaan kerja pada karyawan.

\section{Model fit}

Tabel 7. CMIN

\begin{tabular}{lcclll}
\hline Model & NPAR & CMIN & DF & P & CMIN/DF \\
\hline Default model & 5 & .000 & 0 & & \\
Saturated model & 5 & .000 & 0 & & \\
Independence model & 2 & 5.629 & 3 & .131 & 1.876 \\
\hline
\end{tabular}

Tabel diatas menunjukan CMIN dibawah 5\% dalam model ini baik yaitu : CMIN/DF sebesar 1,876 .

\begin{tabular}{|c|c|c|c|c|c|}
\hline Model & NFI Delta1 & $\begin{array}{l}\text { RFI } \\
\text { rho1 }\end{array}$ & $\begin{array}{l}\text { IFI } \\
\text { Delta2 }\end{array}$ & $\begin{array}{l}\text { TLI } \\
\text { rho2 }\end{array}$ & CFI \\
\hline $\begin{array}{l}\text { Default model } \\
1.000\end{array}$ & & & 1.000 & & 1.000 \\
\hline $\begin{array}{l}\text { Saturated model } \\
1.000\end{array}$ & & & 1.000 & & 1.000 \\
\hline Independence model & .000 & .000 & .000 & .000 & .000 \\
\hline
\end{tabular}

Tabel 8. Baseline Comparisons

CFI menunjukan model pada gambar 4 sudah signifikan yaitu dibawah $1 \%$.

Tabel 9. RMSEA

\begin{tabular}{lllll}
\hline Model & RMSEA & LO 90 & HI 90 & PCLOSE \\
Independence model & .084 & .000 & .190 & .232 \\
\hline
\end{tabular}

RMSEA 0,084 diatas 0,05 ini adalah menunjukan model independent untuk erornya sudah sudah lebih besar dari $5 \%$.

Kesimpulan:

Uji Hipotesis. Signifikan apabila nilai CR $>1,96$ dan nilai $P<0,05$. Hasilnya dapat disimpulkan bahwa HO ditolak, artinya bahwa variabel keselamatan dan kesehatan kerja berpengaruh signifikan terhadap kinerja perusahaan. Kekuatan pengaruh dapat dilihat pada nilai estimate ataupun pada diagram tabel 10 . 


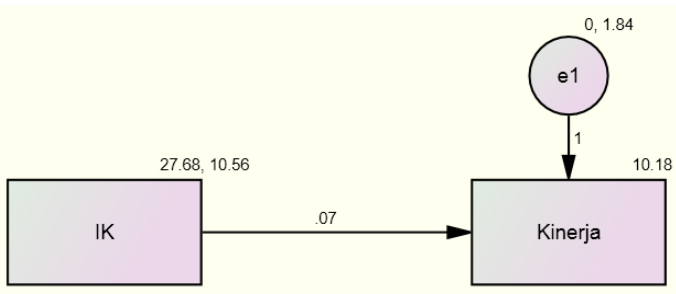

Tabel 10. Regression Weights

\begin{tabular}{lrlrrrr}
\hline Estimate & & S.E. & C.R. & \multicolumn{2}{c}{ P } & \multicolumn{2}{c}{ Label } \\
Kinerja & $<---$ & IK & .065 & .041 & 1.595 & .111 \\
\hline
\end{tabular}

Tabel diatas menunjukan bahwa tidak ada pengaruh signifikan diatas $5 \%$ dengan probabilitas $(P=0,111)$ dan dengan T-hitung sebesar: 1,595.

Tabel 11. Intercepts/koefisien

\begin{tabular}{lllll}
\hline Estimate & S.E. & C.R. & P & Label \\
Kinerja & 10.175 & 1.140 & 8.928 & $* * *$ \\
\hline
\end{tabular}

Sehingga tabel V.12.\&V.13. bisa membentuk metode persamaan regresinya:

$$
\begin{gathered}
Y^{\prime}=a+b X \\
Y^{\prime}=10,175+0,065
\end{gathered}
$$

Angka -angka ini dapat diartikan sebagai berikut:

Intercepts sebesar 10,175; artinya jika iklim kerja (X), nilainya adalah 0, maka Kinerja perusahaan nilainya yaitu sebesar 10,175.

Koefisien regresi variabel $\mathrm{K} 3(\mathrm{X})$ sebesar 0,065 ; artinya jika iklim kerja naik $1 \%$, maka kinerja perusahaan $(Y)$ akan mengalami peningkatan sebesar 0,065 . Koefisien bernilai positif artinya terjadi hubungan positif antara iklim kerja dengan kinerja perusahaan, semakin meningkat iklim/lingkungan kerja yang aman maka semakin meningkatkan kinerja perusahaan tersebut dengan berkurang kecelakaan kerja pada karyawan.

\section{Model fit}

Tabel 12. CMIN

\begin{tabular}{llclll}
\hline Model & NPAR & CMIN & DF & P & CMIN/DF \\
\hline Default model & 5 & .000 & & 0 & \\
Saturated model & 5 & .000 & & 0 & \\
Independence model & 2 & 2.514 & 3 & .473 & .838 \\
\hline
\end{tabular}

Tabel diatas menunjukan CMIN dibawah 5\% dalam model ini baik yaitu : CMIN/DF sebesar 0,838

Tabel 13. Baseline Comparisons

\begin{tabular}{lccccc}
\hline Model & NFI Delta1 & RFI rho1 & IFI Delta2 & TLI rho2 & CFI \\
\hline Default model & .000 & & 1.000 & .000
\end{tabular}




\begin{tabular}{lllr} 
Saturated model & 1.000 & \multicolumn{2}{c}{1.000} \\
$\begin{array}{l}\text { Independence } \\
\text { model }\end{array}$ & .000 & .000 & \\
\hline
\end{tabular}

CFI menunjukan model pada tabel 6. 4 tidak adanyan pengaruh sama sekali.

Tabel 13. RMSEA

\begin{tabular}{lllll}
\hline Model & RMSEA & LO 90 & HI 90 & PCLOSE \\
Independence model & .000 & .000 & .142 & .598 \\
\hline
\end{tabular}

RMSEA 0,000 dibawah 0,001 ini adalah menunjukan model independent untuk erornya lebih kecil dibawah dari $1 \%$.

Kesimpulan:

Uji Hipotesis. Signfikan apabila nilai $C R>1,96$ dan nilai $P<0,05$. Hasilnya dapat disimpulkan bahwa HO diterima, artinya bahwa variabel iklim kerja tidak berpengaruh signifikan terhadap kinerja perusahaan. Tidak adanya pengaruh dapat dilihat pada nilai estimate ataupun pada diagram tabel 14.

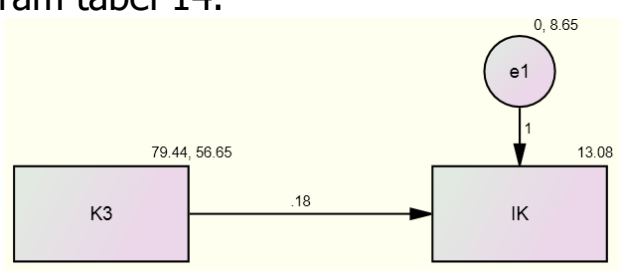

Tabel 14. Regression Weights

\begin{tabular}{|c|c|c|c|c|}
\hline Estimate & S.E. & C.R. & $\mathrm{P}$ & Label \\
\hline IK $<---$ & K3 & .184 & .038 & $4.799 \quad * * *$ \\
\hline
\end{tabular}

Tabel diatas menunjukan signifikan pada $1 \%$ dengan probabilitas $(\mathrm{P}=* * *)$ dan dengan $\mathrm{T}$ hitung $=4,799$.

Tabel 15. Intercepts ( Koefisien)

\begin{tabular}{llllll}
\hline & Estimate & S.E. & C.R. & P & Label \\
IK & 13.080 & 3.055 & 4.281 & $* * *$ & \\
\hline
\end{tabular}

Sehingga tabel V.17.\&V.18. bisa membentuk metode persamaan regresinya:

$$
\begin{gathered}
Y^{\prime}=a+b X \\
Y^{\prime}=13,080+0,184
\end{gathered}
$$

Angka -angka ini dapat diartikan sebagai berikut:

Intercepts sebesar 13,080; artinya jika keselamatan dan kesehatan kerja (K3) (X), nilainya adalah 0, maka Iklim kerja nilainya yaitu sebesar 13,080.

Koefisien regresi variabel $\mathrm{K} 3(\mathrm{X})$ sebesar 0,184 ; artinya jika keselamatan dan kesehatan kerja naik $1 \%$, maka iklim kerja $(Y)$ akan mengalami peningkatan sebesar 0,184. Koefisien bernilai positif artinya terjadi hubungan positif antar keselamatan dan kesehatan kerja 
dengan iklim kerja, semakin meningkat keselamatan dan kesehatan kerja maka semakin meningkatkan iklim kerja yang aman dan nyaman.

Model Fit

Tabel 16. CMIN

\begin{tabular}{llllll}
\hline Model & NPAR & CMIN & DF & P & CMIN/DF \\
\hline Default model & 5 & .000 & 0 & & \\
Saturated model & 5 & .000 & 0 & & \\
Independence & 2 & 20.808 & 3 & .000 & 6.936 \\
\hline
\end{tabular}

Tabel diatas menunjukan CMIN yaitu diatas 5\% dalam model ini baik dengan CMIN/DF : 6,936

Tabel 17. Baseline Comparisons

\begin{tabular}{lcclcl}
\hline Model & NFI Delta1 & RFI rho1 & IFI Delta2 & TLI rho2 & CFI \\
\hline Default model & 1.000 & & 1.000 & & 1.000 \\
Saturated model & 1.000 & & 1.000 & & 1.000 \\
Independence model & .000 & .000 & .000 & .000 & .000 \\
\hline
\end{tabular}

Tabel diatas menunjukan CFI sudah signifikan yaitu dibawah $1 \%$.

Tabel 18. RMSEA

\begin{tabular}{lllll}
\hline Model & RMSEA & LO 90 & HI 90 & PCLOSE \\
Independence model & .219 & .136 & .312 & .001 \\
\hline
\end{tabular}

RMSEA 0,219 diatas 0,05 ini adalah menunjukan model independent untuk erornya sudah sudah lebih besar dari $5 \%$.

Kesimpulan:

Uji Hipotesis. Signfikan apabila nilai $C R>1,96$ dan nilai $P<0,05$. Hasilnya dapat disimpulkan bahwa HO ditolak, artinya bahwa ada pengaruh secara signifikan antara variabel keselamatan dan kesehatan kerja terhadap iklim kerja. Kekuatan pengaruh dapat dilihat pada nilai estimate ataupun pada diagram tabel 19.

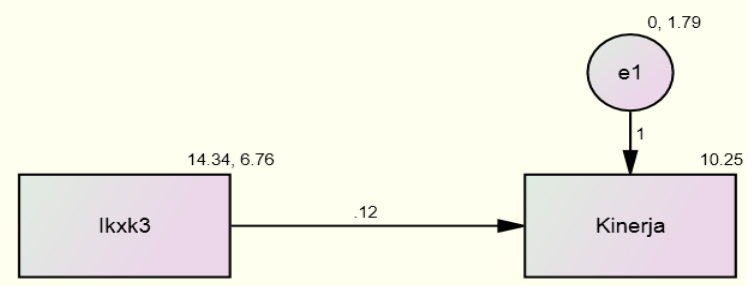

Tabel 19. Regression Weights

\begin{tabular}{lllllll}
\hline Estimate & & S.E. & C.R. & \multicolumn{2}{c}{ P } & \multicolumn{2}{c}{ Label } \\
Kinerja & $<---$ & Ikxk3 & .120 & .050 & 2.390 & .017 \\
\hline
\end{tabular}


Tabel diatas menunjukan probabilitas diatas $1 \%$ yaitu $(P=0,017)$ dan dengan $T$-hitung sebesar: 2,390.

Tabel 20. Intercepts/koefisien

\begin{tabular}{llllll}
\hline & Estimate & S.E. & C.R. & $P$ & Label \\
Kinerja & 10.254 & .735 & 13.958 & $* * *$ & \\
\hline
\end{tabular}

Sehingga tabel V.22.\&V.23. bisa membentuk metode persamaan regresinya:

$$
\begin{gathered}
Y^{\prime}=a+b X \\
Y^{\prime}=10,254+0,120
\end{gathered}
$$

Angka -angka ini dapat diartikan sebagai berikut:

Intercepts sebesar 10,254; artinya jika iklim kerja, keselamatan dan kesehatan kerja (K3) $(X)$, nilainya adalah 0, maka Kinerja perusahaan nilainya yaitu sebesar 10,254.

Koefisien regresi variabel K3 (X) sebesar 0,120; artinya jika iklim kerja,keselamatan dan kesehatan kerja naik $1 \%$, maka kinerja perusahaan $(Y)$ akan mengalami peningkatan sebesar 0,120. Koefisien bernilai positif artinya terjadi hubungan positif antara iklim kerja,keselamatan dan kesehatan kerja dengan kinerja perusahaan, semakin meningkat lingkungan/kerja yang aman, keselamatan dan kesehatan kerja maka semakin meningkatkan kinerja perusahaan tersebut dengan berkurang kecelakaan kerja pada karyawan.

\section{Model fit}

Tabel 21. CMIN

\begin{tabular}{llllll}
\hline Model & NPAR & CMIN & DF & P & CMIN/DF \\
\hline Default model & 5 & & .000 & 0 & \\
Saturated model & 5 & & .000 & 0 & \\
Independence model & 2 & 5.560 & 3 & .135 & 1.853 \\
\hline
\end{tabular}

Tabel diatas menunjukan CMIN dibawah 5\% dalam model ini baik yaitu : CMIN/DF sebesar 1,853 .

Tabel 22. Baseline Comparisons

\begin{tabular}{lcclcr}
\hline Model & NFI Delta1 & RFI rho1 & IFI Delta2 & TLI rho2 & CFI \\
\hline Default model & 1.000 & & 1.000 & & 1.000 \\
Saturated model & 1.000 & & 1.000 & & 1.000 \\
Independence & .000 & .000 & .000 & .000 & .000 \\
model & & & & & \\
\hline
\end{tabular}

Tabel diatas menunjukan CFI sudah signifikan yaitu dibawah $1 \%$ 
Tabel 23. RMSEA

\begin{tabular}{lllll}
\hline Model & RMSEA & LO 90 & HI 90 & PCLOSE \\
Independence model & .083 & .000 & .190 & .237 \\
\hline
\end{tabular}

Tabel diatas menunjukan nilai RMSEA 0,083 yaitu diatas 0,05 ini adalah menunjukan model independent untuk erornya sudah sudah lebih besar dari $5 \%$.

Kesimpulan:

Uji Hipotesis. Signfikan apabila nilai $C R>1,96$ dan nilai $P<0,05$. Hasilnya dapat disimpulkan bahwa HO ditolak, artinya bahwa variabel iklim kerja, keselamatan dan kesehatan kerja (K3)berpengaruh signifikan terhadap kinerja perusahaan. Kekuatan pengaruh dapat dilihat pada nilai estimate ataupun pada diagram tabel 23 .

\section{PEMBAHASAN}

Hasil analisis menunjukkan bahwa variabel keselamatan dan kesehatan kerja (K3) mempunyai pengaruh positif dan signifikan terhadap kinerja perusahaan di Daerah Istimewa Yogyakarta. Hal ini dapat diartikan, jika keselamatan dan kesehatan kerja (K3) meningkat dalam arti bahwa responden menilai Ragu-Ragu konsisten praktek kerja yang aman, memantau isu-isu k3, pengawasan, kondisi kerja, keamanan kerja, perhatian, fasilitas kesejahteraan, manajemen dengan serikat kerja, fasilitas, perhatian manajemen, kepuasan, usaha mencapai keselamatan kerja, mendiskusikan isu-isu keselamatan, manajemen menjamin setiap karyawan menerima informasi, manajemen menjamin keselamatan, manajemen mendorong pekerja berpartisipasi, manajemen mendengarkan tentang kecelakaan kerja, membantu satu sama lain, bertanggung jawab, belajar dari pengalaman, menanggapi penting tujuan keselamatan kerja, pelatihan keselamatan untuk mencegah terjadi kecelakaan kerja. Maka tingkat efektifitas dan produktifitas kinerja perusahaan akan mengalami peningkatan. Hasil penelitian ini mendukung hasil penelitian sebelumnya yang dilakukan oleh Fahmawati (2004), menunjukkan bahwa kesehatan dan keselamatan kerja berpengaruh signifikan terhadap kinerja karyawan.

Hasil analisis menunjukkan bahwa variabel iklim/lingkungan kerja tidak mempunyai pengaruh signifikan terhadap kinerja perusahaan di Daerah Istimewa Yogyakarta, hal ini dapat diartikan, jika iklim/lingkungan kerja meningkat dalam arti bahwa responden menilai Ragu-Ragu kesejahteraan karyawan, ruangan kerja dan iklim kerja yang baik, menjamin berlangsung kerja secara optimal, prosedur keamanan kerja

untuk menjamin keamanan dalam bekerja, dampak kepuasan karyawan, kepuasan secara keseluruhan, aspek tentang bayaran (gaji) dan kondisi kerja. Maka tingkat efektifitas dan produktifitas kinerja perusahaan tidak akan mengalami peningkatan. Hasil penelitian ini tidak mendukung hasil penelitian sebelumnya yang dilakukan oleh Fahmawati (2004), menunjukkan bahwa lingkungan kerja berpengaruh signifikan terhadap

kinerja karyawanHasil analisis menunjukkan bahwa variabel keselamatan dan kesehatan kerja (K3) mempunyai pengaruh positif dan signifikan terhadap

iklim/lingkungan kerja di Daerah Istimewa Yogyakarta, hal ini dapat diartikan, jika keselamatan dan kesehatan kerja (K3) meningkat dalam arti bahwa responden menilai Ragu-Ragu konsisten praktek kerja yang aman,memantau isu-isu $\mathrm{k} 3$, pengawasan, kondisi kerja, keamanan kerja, perhatian, fasilitas kesejahteraan, manajemen dengan serikat kerja, 
fasilitas, perhatian manajemen, kepuasan, usaha mencapai keselamatan kerja, mendiskusikan isu-isu keselamatan, manajemen menjamin setiap karyawan menerima informasi, manajemen menjamin keselamatan, manajemen mendorong pekerja berpartisipasi, manajemen mendengarkan tentang kecelakaan kerja, membantu satu sama lain, bertanggung jawab, belajar dari pengalaman, menanggapi penting tujuan keselamatan kerja, pelatihan keselamatan.untuk mencegah terjadi kecelakaan kerja. Maka tingkat kesejahteraan,kondisi kerja yang aman dan nyaman akan mengalami peningkatan dalam bekerja.Hasil analisis menunjukkan bahwa variabel moderasi iklim/lingkungan kerja serta keselamatan dan kesehatan kerja (K3) mempunyai pengaruh positif dan signifikan terhadap kinerja perusahaan di Daerah Istimewa Yogyakarta, hal ini dapat diartikan, jika iklim/lingkungan kerja serta keselamatan dan kesehatan kerja (K3) meningkat dalam arti bahwa responden menilai Ragu-Ragu kesejahteraan karyawan, ruangan kerja dan Iklim kerja yang baik, menjamin berlangsung kerja secara optimal, prosedur keamanan kerja untuk menjamin keamanan dalam bekerja, dampak kepuasan karyawan, kepuasan secara keseluruhan, aspek tentang bayaran (gaji) dan kondisi kerja serta responden juga menilai netral konsisten praktek kerja yang aman, memantau isu-isu k3, pengawasan, kondisi kerja, keamanan kerja, perhatian, fasilitas kesejahteraan, manajemen dengan serikat kerja, fasilitas, perhatian manajemen, kepuasan, usaha mencapai keselamatan kerja, mendiskusikan isu-isu keselamatan, manajemen menjamin setiap karyawan menerima informasi, manajemen menjamin keselamatan, manajemen mendorong

pekerja berpartisipasi, manajemen mendengarkan tentang kecelakaan kerja, membantu satu sama lain, bertanggung jawab, belajar dari pengalaman, menanggapi penting tujuan keselamatan kerja, pelatihan keselamatan. Untuk mencegah terjadi kecelakaan kerja. Maka semakin meningkat tingkat kesejahteraan, keamanan dan kondisi karyawan dalam bekerja di perusahaan maka berdampak positif dan signifikan pada

keselamatan dan kesehatan kerja dengan berkurang angka kecelakaan kerja yang terjadi pada saat bekerja berpengaruh signifikan dan akan memperkuat pula terhadap efektifitas dan produktifitas kinerja perusahaan. Hasil penelitian ini mendukung hasil penelitian sebelumnya yang dilakukan oleh Fahmawati (2004), menunjukkan bahwa kesehatan dan keselamatan kerja serta lingkungan kerja mempunyai pengaruh yang signifikan terhadap kinerja karyawan.

\section{KESIMPULAN}

1. Variabel keselamatan dan kesehatan kerja (K3) mempunyai pengaruh secara signifikan terhadap kinerja perusahaan di provinsi Daerah Istimewa Yogyakarta. Hal ini ditunjukkan oleh nilai probabilitas-statistik $=0,016<$ Level of Significant $=0,05$.

2. Variabel iklim kerja tidak mempunyai pengaruh yang signifikan terhadap kinerja perusahaan di provinsi Daerah Istimewa Yogyakarta. Hal ini ditunjukkan oleh nilai probabilitas-statistik $=0,111>$ Level of Significant $=0,05$.

3. Variabel keselamatan dan kesehatan kerja (K3) mempunyai pengaruh yang signifikan terhadap iklim/lingkungan kerja di provinsi Daerah Istimewa Yogyakarta. Hal ini ditunjukkan oleh nilai probabilitas-statistik $=0,001<$ Level of Significant $=0,05$.

4. Variabel moderasi iklim kerja serta keselamatan dan kesehatan kerja (K3) mempunyai pengaruh yang signifikan terhadap kinerja perusahaan di provinsi Daerah Istimewa 
Yogyakarta. Hal ini ditunjukkan oleh nilai probabilitas-statistik $=0,017<$ Level of Significant $=0,05$.

\section{SARAN}

1. perusahaan selalu memperhatikan keselamatan dan kesehatan kerja karyawannya agar dapat menciptakan keamanan dan kenyamanan karyawan dalam bekerja untuk meningkatkan efektifitas dan produktivitas kinerja sumber daya manusia dan kinerja perusahaan yang unggul

2. peneliti selanjutnya, agar dapat mengembangkan hasil penelitian ini dengan mengangkat objek penelitian pada perusahaan atau instansi lainnya dan dengan jenis pekerjaan yang berbeda dan menambahkan variabel-variabel keselamatan dan kesehatan kerja (K3) dan Iklim kerja yang memiliki pengaruh terhadap kinerja perusahaan.

\section{DAFTAR PUSTAKA}

Chan Simon and Wai-ming Mak, 2012, High Performance Human Resource Practices And Organizational Performance The Mediating Role Of Occupational Safety And Health Department Of Management And Marketing, Hong Kong : The Hong Kong Polytechnic University.

Suhartini, 2013, Kesehatan Dan Keselamatan Kerja Pada PT. Metro Abdi Bina Sentosa. Surabaya : Institut Teknologi Adhi Tama Surabaya.

Handayani Wiena, 2009, Identifikasi Bahaya Keselamatan Dan Upaya Pengendalian Pada Proses Pengelasan Listrik Di Bengkel Umum Unit 5-7 PT. Indonesia Power Ubp Suralaya Tahun 2009, Jakarta : UIN syarif Hidayatullah Jakarta.

Arka I Gusti Made, 2008, Departemen Tenaga Kerja Dan Transmigrasi R.I. Direktorat Jenderal Pembinaan Pengawasan Ketenagakerjaan, Jakarta.

Perdana Adrians, Fuadi A. Nasution, J. Sudirwan, 2012, Analisis Kecelakaan Kerja Untuk Peningkatan Produktivitas Dengan Penerapan Sistem Informasi Pada Pt Artistika Kreasi Mandiri : Binus University

Aktami Bayu, 2014, Kontribusi Kepuasan Kerja Dan Iklim Organisasi Terhadap Komitmen Karyawan : Universitas Gunadarma

Rusindiyanto, 2014, Analisis Kinerja Sumber Daya Manusia Dengan Metode Human Resources Scorecard (Hrsc) (Studi Kasus Di Pt. Arto Metal Internasional Sidoarjo), Jawa Timur : Teknik Industri FTI UPNV.

Kani Bobby Rocky Kani R. J. M. Mandagi, J. P. Rantung, G. Y. Malingkas, 2013, Keselamatan Dan Kesehatan Kerja Pada Pelaksanaan Proyek Konstruksi (Studi Kasus: Proyek Pt. Trakindo Utama) : Universitas Sam Ratulangi.

Grahanintyas Dewinta, Sritomo Wignjosoebroto, Effi Latiffianti Analisa, 2012, Keselamatan

Dan Kesehatan Kerja (K3) Dalam Meningkatkan Produktivitas Kerja (Studi Kasus: Pabrik Teh Wonosari PTPN XII) : Institut Teknologi Sepuluh November.

Anggoroh, M Toha, dkk. 2008, Metode Penelitian : Universitas Terbuka.

Mixed John W, Cresswell, 2012, Research Design ; Pendekatan Kualitatif, Kuantitatif : Pustaka Pelajar.

Arikunto, Suharsimi. 2010. Prosedur Penelitian. Jakarta : PT. Rineka Cipta.

Handoko Hani. T, 1995, Manajemen ; Edisi revisi 2, Yogyakarta : BPFE.2014, Pengaruh Sikap Pengetahuan Keselamatan Kerja Dan Iklim Keselamatan Kerja Terhadap 
Perilaku Keselamatan Pada Karyawan Produksi Pt. Semen Indonesia (Persero) Tbk, Universitas Negeri Malang.

www.depnakertrans.go.id/news, diakses pada tanggal 13 Oktober, 2014

Sindonews.com/2013/sektor riil_peserta jamsostek alami kecelakaan pekerja.html

Martoyo Susilo, 1987, Manajemen Sumber Daya Manusia Edisi Revisi,Yogyakarta : BPFE

Daerah Istimewa Yogyakarta Dalam Angka, 2013 : BPS Provinsi D.I. Yogyakarta. 